\title{
Policy Cycle of the Urban Agenda for EU and Its Effects on Territorial Cohesion
}

\author{
Territorial Cohesion pp 153-172 | Cite as
}

- Paulo Neto (1) Email author (neto@uevora.pt)

- Maria Manuel Serrano (2)

- Anabela Santos (3)

1. Department of Economics, University of Évora, Public Policy Monitoring Unit (UMPP), CICS.NOVA.UÉvora and CEFAGE-UÉ, , Évora, Portugal

2. Department of Sociology, University of Évora, Public Policy Monitoring Unit (UMPP), CICS.NOVA.UÉvora and SOCIUS-CSG/ISEG-UL, , Évora, Portugal

3. International Centre for Innovation, Technology and Education Studies (iCite), Solvay Brussels School of Economics and Management, Université Libre de Bruxelles, , Brussels, Belgium

Chapter

First Online: 15 December 2018

- 32 Downloads

Part of the The Urban Book Series book series (UBS)

\begin{abstract}
This chapter aims to analyse how, in the European Union's public policy set, policies directed to cities and urban matters have become more relevant. The importance of these policies in the European agenda is seen in Cohesion Policy, but also in the Union's other policies, with other thematic and sector focuses. The intention is also to analyse to what extent the transversal, trans-sector, multi-scale and transpolicy character-which urban questions have acquired in European policies-are contributing to the development of a new generation of public, national and regional policies, and to achieving higher levels of territorial cohesion. The pertinence of this research is reinforced by the creation of the Urban Agenda for EU, created in 2016 by the European Union, which aims to systematise and reorganise the different Union policies directed to cities and revalue their role in the process of European integration.
\end{abstract}

\section{Keywords}

Urban agenda Policy cycle EU cohesion policy European Union

Territorial cohesion

This is a preview of subscription content, $\underline{\log } \underline{\text { in }}$ to check access.

\section{Notes}




\section{Acknowledgements}

The authors are grateful to Eduardo Medeiros, the editor, for the invitation to participate in this book.

\section{References}

Atkinson R (2014) The urban dimension in cohesion policy: past developments and future prospects. In: Paper presented at an RSA workshop on 'The New Cycle of the Cohesion Policy in 2014-2020'. Institute for European Studies, Vrije Universiteit Brussels, 24 March 2014 Google Scholar (https://scholar.google.com/scholar? q=Atkinson\%20R\%20\%282014\%29\%20The\%20urban\%2odimension\%2oin\%20cohe sion\%2opolicy\%3A\%2opast\%2odevelopments\%20and\%2ofuture\%2oprospects.\%20I n\%3A\%20Paper\%2opresented\%20at\%20an\%20RSA\%20workshop\%20on\%20\%E2\% 80\%98The\%20New\%2oCycle\%20of\%20the\%20Cohesion\%2oPolicy\%2oin\%2020142020\%E2\%80\%99.\%20Institute\%20for\%20European\%20Studies\%2C\%20Vrije\%20U niversiteit\%20Brussels\%2C\%2024\%20March\%202014)

Barca F (2009) An agenda for a reformed cohesion policy. A place-based approach to meeting European Union challenges and expectations. Independent report prepared at the request of Danuta Hübner, Commissioner for Regional Policy

Google Scholar (https://scholar.google.com/scholar?

q=Barca\%20F\%20\%282009\%29\%20An\%20agenda\%20for\%20a\%2oreformed\%20co hesion\%2opolicy.\%20A\%2oplace-

based\%20approach\%20to\%2omeeting\%20European\%2oUnion\%20challenges\%20an d\%20expectations.\%2oIndependent\%2oreport\%2oprepared\%20at\%2othe\%2oreques t\%20of\%2oDanuta\%20H\%C3\%BCbner\%2C\%20Commissioner\%2ofor\%2oRegional\% 20Policy)

De Bruijn M, Zuber P, Piskorz W, Rózsa J (2015) Scenarios for integrated territorial investments. In: European Commission, Directorate-General for Regional Policy. Publications Office of the European Union, Luxembourg Google Scholar (https://scholar.google.com/scholar? q=De\%2oBruijn\%20M\%2C\%2oZuber\%2oP\%2C\%2oPiskorz\%2oW\%2C\%2oR\%C3\%B 3Zsa\%2OJ\%20\%282015\%29\%20Scenarios\%2ofor\%2ointegrated\%2oterritorial\%20inv estments.\%20In\%3A\%2oEuropean\%20Commission\%2C\%20Directorate-

General\%2ofor\%2oRegional\%2oPolicy.\%20Publications\%20Office\%20of\%20the\%20 European\%20Union\%2C\%20Luxembourg)

Dijkstra L, Athanasoglou S (2015) The Europe 2020 index: the progress of EU countries, regions and cities to the 2020 targets. European Commission, Regional and Urban Policy, Regional Focus 01/2015, May 2015

Google Scholar (https://scholar.google.com/scholar?

q=Dijkstra\%20L\%2C\%20Athanasoglou\%20S\%20\%282015\%29\%20The\%20Europe\% 202020\%20index\%3A\%20the\%2oprogress\%20of\%20EU\%2ocountries\%2C\%2oregio ns\%20and\%20cities\%20to\%20the\%202020\%20targets.\%2oEuropean\%20Commissio n\%2C\%2oRegional\%20and\%2oUrban\%2oPolicy\%2C\%2ORegional\%2oFocus\%2001\% 2F2015\%2C\%20May\%202015)

EUKN (2011) Cohesion policy in urban practice. European Urban Knowledge Network, The Netherlands 
Google Scholar (http://scholar.google.com/scholar_lookup?

title=Cohesion\%2opolicy\%20in\%2ourban\%2opractice\&publication_year=2011)

European Commission (1997) Towards an urban agenda in the European Union, COM (97) 197 final

Google Scholar (https://scholar.google.com/scholar?

q=European\%20Commission\%20\%281997\%29\%20Towards\%20an\%2ourban\%20age nda\%20in\%2othe\%20European\%20Union\%2C\%20COM\%20\%2897\%29\%20197\%20f inal)

European Commission (1998) Sustainable urban development in the European Union: a framework for action, COM (1998) 605 final

Google Scholar (https://scholar.google.com/scholar?

q=European\%20Commission\%20\%281998\%29\%20Sustainable\%20urban\%2odevelop ment\%20in\%2othe\%2oEuropean\%20Union\%3A\%20a\%2oframework\%2ofor\%20acti on\%2C\%20COM\%20\%281998\%29\%20605\%20final)

European Commission (2006) Cohesion policy and cities: the urban contribution to growth and jobs in the regions. COM (2006) 385 final

Google Scholar (https://scholar.google.com/scholar?

q=European\%20Commission\%20\%282006\%29\%20Cohesion\%2opolicy\%20and\%20c ities\%3A\%20the\%2ourban\%2ocontribution\%20to\%2ogrowth\%20and\%20jobs\%2oin \%20the\%2oregions.\%20COM\%20\%282006\%29\%20385\%20final)

European Commission (2007) The urban dimension in community policies for the period 2007-2013. European Commission, Directorate General Regional Policy, Brussels

Google Scholar (https://scholar.google.com/scholar? q=European\%20Commission\%20\%282007\%29\%20The\%20urban\%2odimension\%20 in\%20community\%2opolicies\%2ofor\%20the\%2operiod\%202007-

2013.\%20European\%20Commission\%2C\%20Directorate\%2oGeneral\%20Regional\%2 oPolicy\%2C\%2oBrussels)

European Commission (2008) Fostering the urban dimension: analysis of the operational programmes co-financed by the European Regional Development Fund (2007-2013). Working Document of the Directorate General for Regional Policy, Brussels, 25 November 2008

Google Scholar (https://scholar.google.com/scholar?

q=European\%20Commission\%20\%282008\%29\%20Fostering\%20the\%20urban\%2od imension\%3A\%20analysis\%20of\%20the\%20operational\%2oprogrammes\%20co-

financed\%20by\%20the\%2oEuropean\%20Regional\%2oDevelopment\%20Fund\%20\%2 82007-

2013\%29.\%20Working\%20Document\%20of\%20the\%2oDirectorate\%20General\%2of or\%20Regional\%2oPolicy\%2C\%2oBrussels\%2C\%2025\%2oNovember\%202008)

European Commission (2009) Promoting sustainable urban development in Europe. Achievements and opportunities. European Commission, Directorate-General for Regional Policy. Publications Office of the European Union, Luxembourg. https://doi.org/10.2776/85168 (https://doi.org/10.2776/85168)

European Commission (2010) Europe 2020-a European strategy for smart, sustainable and inclusive growth. COM (2010) 2020 final

Google Scholar (https://scholar.google.com/scholar?

q=European\%20Commission\%20\%282010\%29\%20Europe\%202020\%E2\%80\%94a\% 20European\%20strategy\%20for\%20smart\%2C\%20sustainable\%20and\%20inclusive\% 2ogrowth.\%20COM\%20\%282010\%29\%202020\%20final)

European Commission (2011a) Cohesion policy 2014-2020, investing in growth and jobs. European Commission, Directorate-General for Regional Policy, Belgium 
Google Scholar (https://scholar.google.com/scholar?

q=European\%20Commission\%20\%282011a\%29\%20Cohesion\%2opolicy\%2020142020\%2C\%20investing\%20in\%2ogrowth\%20and\%2ojobs.\%20European\%20Commis sion\%2C\%2oDirectorate-General\%20for\%20Regional\%20Policy\%2C\%2oBelgium)

European Commission (2011b) Cities of tomorrow-challenges, visions, ways forward. European Commission, Directorate-General for Regional Policy. Publications Office of the European Union, Luxembourg

Google Scholar (https://scholar.google.com/scholar?

q=European\%20Commission\%20\%282011b\%29\%20Cities\%20of\%20tomorrow\%E2\% 80\%94challenges\%2C\%20visions\%2C\%20ways\%2oforward.\%2oEuropean\%20Comm ission\%2C\%20Directorate-

General\%2ofor\%2oRegional\%2oPolicy.\%20Publications\%20Office\%20of\%2othe\%20 European\%20Union\%2C\%20Luxembourg)

European Commission (2014) The urban dimension of EU policies-key features of an EU urban agenda. COM (2014) 490 final

Google Scholar (https://scholar.google.com/scholar?

q=European\%20Commission\%20\%282014\%29\%20The\%2ourban\%2odimension\%20 of\%2oEU\%2opolicies\%E2\%80\%94key\%2ofeatures\%20of\%20an\%2oEU\%2ourban\%2 oagenda.\%20COM\%20\%282014\%29\%20490\%20final)

European Commission (2016a) The State of European Cities 2016. Cities leading the way to a better future. European Commission, Directorate-General for Regional and Urban Policy. Publications Office of the European Union, Luxembourg.

https://doi.org/10.2776/643506 (https://doi.org/10.2776/643506)

European Commission (2016b) Establishing the urban agenda for the EU 'Pact of Amsterdam'. Agreed at the Informal Meeting of EU Ministers Responsible for Urban Matters on 30 May 2016 in Amsterdam

Google Scholar (https://scholar.google.com/scholar?

q=European\%20Commission\%20\%282016b\%29\%20Establishing\%20the\%2ourban\% 20agenda\%2ofor\%20the\%20EU\%20\%E2\%80\%98Pact\%20of\%20Amsterdam\%E2\%8 0\%99.\%20Agreed\%20at\%2othe\%2oInformal\%2oMeeting\%20of\%2oEU\%2oMinisters \%20Responsible\%2ofor\%2oUrban\%2oMatters\%20on\%2030\%20May\%202016\%20in \%20Amsterdam)

European Commission (2017) Seventh report on economic, social and territorial cohesion. European Commission, Directorate-General for Regional and Urban Policy, Belgium. https://doi.org/10.2776/176864 (https://doi.org/10.2776/176864)

European Commission (2018a) SWD(2018) 283 final-staff working document executive summary of the impact assessment accompanying the document proposals for a regulation of the European Parliament and of the Council on the European Regional Development Fund and on the Cohesion Fund on a mechanism to resolve legal and administrative obstacles in a cross-border context on specific provisions for the European territorial cooperation goal (Interreg) supported by the European Regional Development Fund and external financing instruments, Strasbourg Google Scholar (https://scholar.google.com/scholar?

q=European\%20Commission\%20\%282018a\%29\%20SWD\%282018\%29\%20283\%2of inal\%E2\%80\%94staff\%20working\%2odocument\%2oexecutive\%20summary\%20of\%2 othe\%2oimpact\%20assessment\%20accompanying\%20the\%2odocument\%2oproposal s\%20for\%20a\%2oregulation\%20of\%20the\%2oEuropean\%2oParliament\%20and\%20 of\%20the\%20Council\%20on\%20the\%2oEuropean\%20Regional\%2oDevelopment\%20 Fund\%20and\%20on\%2othe\%20Cohesion\%20Fund\%20on\%20a\%2omechanism\%20t о\%2oresolve\%2olegal\%20and\%20administrative\%20obstacles\%20in\%20a\%20crossborder\%20context\%20on\%20specific\%20provisions\%2ofor\%2othe\%2oEuropean\%20 
territorial\%20cooperation\%20goal\%20\%28Interreg\%29\%20supported\%2oby\%2othe \%20European\%20Regional\%2oDevelopment\%2oFund\%20and\%2oexternal\%2ofinan cing\%20instruments\%2C\%20Strasbourg)

European Commission (2018b) Proposal for a regulation of the European Parliament and of the Council laying down common provisions on the European Regional Development Fund, the European Social Fund Plus, the Cohesion Fund, and the European Maritime and Fisheries Fund and financial rules for those and for the Asylum and Migration Fund, the Internal Security Fund and the Border Management and Visa Instrument. COM (2018) 375 final

Google Scholar (https://scholar.google.com/scholar?

q=European\%20Commission\%20\%282018b\%29\%2oProposal\%2ofor\%20a\%2oregula tion\%20of\%2othe\%2oEuropean\%2oParliament\%20and\%20of\%20the\%20Council\%2 olaying\%20down\%20common\%2oprovisions\%20on\%2othe\%2oEuropean\%2oRegion al\%20Development\%20Fund\%2C\%20the\%2oEuropean\%20Social\%2oFund\%2oPlus \%2C\%20the\%20Cohesion\%2oFund\%2C\%20and\%2othe\%2oEuropean\%2oMaritime\% 20and\%20Fisheries\%20Fund\%20and\%2ofinancial\%2orules\%2ofor\%2othose\%20and \%2ofor\%2othe\%20Asylum\%20and\%2oMigration\%2oFund\%2C\%20the\%2oInternal\% 2oSecurity\%2oFund\%20and\%2othe\%2oBorder\%2oManagement\%2oand\%2oVisa\%2 oInstrument.\%20COM\%20\%282018\%29\%20375\%20final)

European Commission (2018c) Staff working document executive summary of the impact assessment accompanying the document Proposals for a Regulation of the European Parliament and of the Council on the European Regional Development Fund and on the Cohesion Fund on a mechanism to resolve legal and administrative obstacles in a cross-border context on specific provisions for the European territorial cooperation goal (Interreg) supported by the European Regional Development Fund and external financing instruments. SWD(2018) 283 final

Google Scholar (https://scholar.google.com/scholar?

q=European\%20Commission\%20\%282018c\%29\%20Staff\%20working\%20document \%20executive\%20summary\%20of\%20the\%2oimpact\%20assessment\%20accompanyi ng\%20the\%2odocument\%20Proposals\%2ofor\%20a\%2oRegulation\%2oof\%2othe\%20 European\%2oParliament\%20and\%20of\%20the\%20Council\%20on\%20the\%2oEurope an\%2oRegional\%2oDevelopment\%2oFund\%20and\%20on\%2othe\%2oCohesion\%2oF und\%20on\%20a\%20mechanism\%20to\%20resolve\%2olegal\%20and\%20administrativ e\%20obstacles\%2oin\%20a\%2ocross-

border\%20context\%20on\%20specific\%2oprovisions\%2ofor\%2othe\%2oEuropean\%20 territorial\%20cooperation\%20goal\%20\%28Interreg\%29\%2osupported\%2oby\%2othe \%20European\%20Regional\%2oDevelopment\%2oFund\%2oand\%2oexternal\%2ofinan cing\%20instruments.\%20SWD\%282018\%29\%20283\%20final)

European Parliament (2014) The role of cities in cohesion policy 2014-2020.

European Parliament's Committee on Regional Development, Belgium

Google Scholar (https://scholar.google.com/scholar?

q=European\%2oParliament\%20\%282014\%29\%20The\%2orole\%20of\%2ocities\%2oin \%20cohesion\%20policy\%202014-

2020.\%20European\%2oParliament\%E2\%80\%99s\%20Committee\%20on\%2oRegional \%2oDevelopment\%2C\%2oBelgium)

European Parliament (2017) Report on building blocks for a post-2020 EU cohesion policy (2016/2326(INI)), Committee on Regional Development

Google Scholar (https://scholar.google.com/scholar?

q=European\%2oParliament\%20\%282017\%29\%2oReport\%20on\%2obuilding\%2obloc ks\%2ofor\%20a\%2opost-

2020\%20EU\%20cohesion\%2opolicy\%20\%282016\%2F2326\%28INI\%29\%29\%2C\%20

Committee\%20on\%2oRegional\%2oDevelopment) 
European Union (2013a) Regulation (EU) $\mathrm{N}^{\circ}$ 1300/2013 of the European Parliament and of the Council of 17 December 2013 on the Cohesion Fund and repealing Council Regulation (EC) No 1084/2006. Off J Eur Union L 347:281-288 (20.12.2013)

Google Scholar (https://scholar.google.com/scholar? q=European\%20Union\%20\%282013a\%29\%20Regulation\%20\%28EU\%29\%20N\%C2 \%Bo\%201300\%2F2013\%20of\%2othe\%2oEuropean\%2oParliament\%20and\%20of\%2 othe\%20Council\%20of\%2017\%2oDecember\%202013\%20on\%20the\%20Cohesion\%2 oFund\%20and\%2orepealing\%20Council\%20Regulation\%20\%28EC\%29\%20No\%201 084\%2F2006.\%20Off\%20J\%2oEur\%2oUnion\%2oL\%2O347\%3A281\%E2\%80\%93288 \%20\%2820.12.2013\%29)

European Union (2013b) Regulation (EU) N ${ }^{\circ}$ 1301/2013 of European Parliament and of the Council of 17 December 2013 on the European Regional Development Fund and on specific provisions concerning the Investment for growth and jobs goal and repealing Regulation (EC) No 1080/2006. Off J Eur Union L 347:289-302

(20.12.2013)

Google Scholar (https://scholar.google.com/scholar? q=European\%20Union\%20\%282013b\%29\%20Regulation\%20\%28EU\%29\%20N\%C2 \%Bo\%201301\%2F2013\%20of\%2oEuropean\%20Parliament\%20and\%20of\%2othe\%20 Council\%20of\%2017\%2oDecember\%202013\%20on\%20the\%2oEuropean\%2oRegiona 1\%20Development\%2oFund\%20and\%20on\%20specific\%2oprovisions\%20concerning \%2othe\%2oInvestment\%2ofor\%2ogrowth\%20and\%2ojobs\%2ogoal\%20and\%2orepea ling\%20Regulation\%20\%28EC\%29\%20No\%201080\%2F2006.\%20Off\%2OJ\%20Eur\% 2oUnion\%20L\%20347\%3A289\%E2\%80\%93302\%20\%2820.12.2013\%29)

European Union (2016) Quality of life in European cities 2015. Publications Office of the European Union, Luxembourg

Google Scholar (https://scholar.google.com/scholar?

q=European\%20Union\%20\%282016\%29\%20Quality\%20of\%2olife\%20in\%20Europe an\%20cities\%202015.\%20Publications\%20Office\%20of\%20the\%2oEuropean\%2oUni on\%2C\%2oLuxembourg)

Ferry M, McMaster I, Zwet A (2018) Assessing the performance of integrated territorial and urban strategies: challenges, emerging approaches and options for the future. European Commission, Directorate-General for Regional and Urban Policy and European Policies Research Centre (EPRC). Publications Office of the European Union, Luxembourg. https://doi.org/10.2776/96617

(https://doi.org/10.2776/96617)

Gagliardi L, Percoco M (2017) The impact of European cohesion policy in urban and rural regions. Reg Stud 51(6):857-868.

https://doi.org/10.1080/00343404.2016.1179384

(https://doi.org/10.1080/00343404.2016.1179384)

CrossRef (https://doi.org/10.1080/00343404.2016.1179384)

Google Scholar (http://scholar.google.com/scholar_lookup?

title=The\%20impact\%20of\%2oEuropean\%20cohesion\%2opolicy\%2oin\%20urban\%2 oand\%20rural\%20regions\&author=L.\%20Gagliardi\&author=M.\%20Percoco\&journal $=$ Reg\%20Stud\&volume $=51$ \&issue $=6 \&$ pages $=857-$

868\&publication_year $=2017 \&$ doi $=10.1080 \% 2 F 00343404.2016 .1179384)$

Glaeser EL (2000) The new economics of urban and regional growth. In: Clark GL, Feldman MP, Gertler MS, Williams K (eds) The Oxford handbook of economic geography. Oxford University Press, pp 83-98

Google Scholar (https://scholar.google.com/scholar?

q=Glaeser\%20EL\%20\%282000\%29\%20The\%20new\%20economics\%20of\%2ourban \%20and\%2oregional\%2ogrowth.\%20In\%3A\%20Clark\%20GL\%2C\%2oFeldman\%20M P\%2C\%2OGertler\%2OMS\%2C\%20Williams\%20K\%20\%28eds\%29\%20The\%20Oxford 
\%2ohandbook\%20of\%2oeconomic\%2ogeography.\%20Oxford\%2oUniversity\%2oPres s\%2C\%20pp\%2083\%E2\%80\%9398)

Lavalle C, Pontarollo N, Batista e Silva F, Baranzelli C, Jacobs C, Kavalov B, Kompil M, Perpiña Castillo C, Vizcaino M, Ribeiro Barranco R, Vandecasteele I, Pinto Nunes Nogueira Diogo V, Aurambout J, Serpieri C, Marín Herrera M, Rosina K, Ronchi S, Auteri D (2017) European territorial trends-facts and prospects for cities and regions. European Commission, Joint Research Centre. Publications Office of the European Union, Luxembourg. https://doi.org/10.2760/148283

(https://doi.org/10.2760/148283)

Medeiros E (2016) Is there a rise of the territorial dimension in the EU Cohesion

Policy? Finisterra, LI 103(2016):89-112. https://doi.org/10.18055/Finis7940

(https://doi.org/10.18055/Finis7940)

CrossRef (https://doi.org/10.18055/Finis7940)

Google Scholar (http://scholar.google.com/scholar_lookup?

title=Is\%20there\%20a\%20rise\%20of\%20the\%2oterritorial\%2odimension\%20in\%20t he\%20EU\%20Cohesion\%2oPolicy\%3F\&author=E.\%20Medeiros\&journal=Finisterra\% 2C\%20LI\&volume $=103$ \&issue $=2016$ \&pages $=89$ -

112\&publication_year $=2016 \&$ doi $=10.18055 \% 2$ FFinis7940)

Medina MG, Fedeli V (2015) Exploring European urban policy: towards an EUnational urban agenda? Gestión y Análisis de Políticas Públicas, Nueva Época, no 14 julio-diciembre 2015

Google Scholar (https://scholar.google.com/scholar?

q=Medina\%20MG\%2C\%20Fedeli\%20V\%20\%282015\%29\%20Exploring\%2oEuropea n\%2ourban\%2opolicy\%3A\%2otowards\%20an\%20EU-

national\%2ourban\%20agenda\%3F\%20Gesti\%C3\%B3n\%20y\%20An\%C3\%A1lisis\%2od e\%20Pol\%C3\%ADticas\%2oP\%C3\%BAblicas\%2C\%2oNueva\%20\%C3\%89poca\%2C\%2 ono\%2014\%20julio-diciembre\%202015)

METIS (2016a) The growth potential of an integrated EU urban agenda. European Committee of the Regions, Belgium

Google Scholar (https://scholar.google.com/scholar?

q=METIS\%20\%282016a\%29\%20The\%2ogrowth\%2opotential\%20of\%20an\%2ointegr ated\%20EU\%2Ourban\%20agenda.\%20European\%20Committee\%20of\%20the\%2oRe gions\%2C\%2oBelgium)

METIS (2016b) Ex post evaluation of urban development and social infrastructuresfinal report. Work Package 10 in Ex post evaluation of Cohesion Policy programmes 2007-2013, focusing on the European Regional Development Fund (ERDF) and the Cohesion Fund (CF), European Commission, Directorate-General for Regional and Urban Policy, Belgium

Google Scholar (https://scholar.google.com/scholar?

q=METIS\%20\%282016b\%29\%20Ex\%2opost\%20evaluation\%20of\%2ourban\%2odeve lopment\%20and\%20social\%20infrastructures\%E2\%80\%94final\%2oreport.\%20Work \%20Package\%2010\%20in\%20Ex\%2opost\%2oevaluation\%20of\%20Cohesion\%2oPolic y\%2oprogrammes\%202007-

2013\%2C\%2ofocusing\%20on\%20the\%2oEuropean\%2oRegional\%2oDevelopment\%2 oFund\%20\%28ERDF\%29\%20and\%20the\%20Cohesion\%20Fund\%20\%28CF\%29\%2C \%20European\%20Commission\%2C\%2oDirectorate-

General\%2ofor\%2oRegional\%20and\%2oUrban\%2oPolicy\%2C\%2oBelgium)

Nabielek K, Hamers D, Evers D (2016) Cities in Europe-facts and figures on cities and urban areas, PBL Netherlands Environmental Assessment Agency. PBL Publishers, The Hague 
Google Scholar (http://scholar.google.com/scholar_lookup?

title=Cities\%20in\%20Europe\%E2\%80\%94facts\%20and\%2ofigures\%200n\%20cities\% 20and\%20urban\%20areas\%2C\%20PBL\%2oNetherlands\%20Environmental\%20Asses sment\%2OAgency\&author=K.\%20Nabielek\&author=D.\%2OHamers\&author=D.\%20E vers\&publication_year=2016)

Neto P (2014) Identity and plasticity in the reshaping processes of urban landscape. In: Proceedings of the 1oth meeting of the workshops of the council of Europe for the implementation of the European landscape convention, Évora, Portugal, 20-21 octobre 2011. European spatial planning and landscape, no. 97. Council of Europe Publishing, Strasbourg, pp 81-91

Google Scholar (https://scholar.google.com/scholar? q=Neto\%2oP\%20\%282014\%29\%2oIdentity\%20and\%2oplasticity\%2oin\%2othe\%2or eshaping\%2oprocesses\%20of\%20urban\%2olandscape.\%20In\%3A\%2oProceedings\%2 oof\%20the\%2010th\%20meeting\%20of\%2othe\%20workshops\%20of\%20the\%20coun cil\%20of\%20Europe\%2ofor\%20the\%20implementation\%20of\%20the\%2oEuropean\% 2olandscape\%20convention\%2C\%20\%C3\%89vora\%2C\%20Portugal\%2C\%2020-

21\%20octobre\%202011.\%20European\%20spatial\%2oplanning\%20and\%2olandscape \%2C\%20no.\%2097.\%20Council\%20of\%2oEurope\%20Publishing\%2C\%20Strasbourg \%2C\%20pp\%2081\%Е2\%80\%9391)

Neto P (2017) Post-2020 cohesion policy and the new challenges for public policy, conference presented, as keynote speaker, at the official dinner of the international seminar on social services of general interest and territorial cohesion: experiences and challenges, organized by the Portuguese Agency for Development and Cohesion

(AD\&C) I.P., Évora Hotel, November 13, 2017, Évora, Portugal

Google Scholar (https://scholar.google.com/scholar?

q=Neto\%20P\%20\%282017\%29\%20Post-

2020\%20cohesion\%20policy\%20and\%20the\%20new\%20challenges\%2ofor\%2opubli c\%2opolicy\%2C\%20conference\%2opresented\%2C\%20as\%2okeynote\%2ospeaker\%2C \%20at\%2othe\%20official\%2odinner\%20of\%2othe\%2ointernational\%2oseminar\%20 on\%20social\%20services\%20of\%2ogeneral\%2ointerest\%20and\%2oterritorial\%20coh esion\%3A\%20experiences\%20and\%2Ochallenges\%2C\%20organized\%20by\%20the\%2 oPortuguese\%20Agency\%2ofor\%2oDevelopment\%20and\%20Cohesion\%20\%28AD\% 26C\%29\%2OI.P.\%2C\%20\%C3\%89vora\%20Hotel\%2C\%2ONovember\%2O13\%2C\%2O2 017\%2C\%20\%C3\%89vora\%2C\%20Portugal)

Neto P, Serrano MM, Santos A (2018) Renewed challenges for public policies in post2020 cohesion policy. From RIS3 to RIS4 and a new social dimension for smart specialisation. Publ Policy Portuguese J 3(1):7-25

Google Scholar (https://scholar.google.com/scholar?

q=Neto\%20P\%2C\%20Serrano\%20MM\%2C\%20Santos\%20A\%20\%282018\%29\%20Re newed\%20challenges\%2ofor\%2opublic\%20policies\%2oin\%2opost-

2020\%20cohesion\%2opolicy.\%20From\%20RIS3\%20to\%20RIS4\%20and\%20a\%20ne w\%20social\%2odimension\%2ofor\%20smart\%2ospecialisation.\%2oPubl\%20Policy\%2 oPortuguese\%20J\%203\%281\%29\%3A7\%E2\%80\%9325)

Zwet A, Bachtler J, Ferry M, McMaster I, Miller S (2017) Integrated territorial and urban strategies: how are ESIF adding value in 2014-2020? European Commission, Directorate-General for Regional and Urban Policy and European Policies Research Centre (EPRC). Publications Office of the European Union, Luxembourg.

https://doi.org/10.2776/50425 (https://doi.org/10.2776/50425)

CrossRef (https://doi.org/10.2776/50425)

Google Scholar (http://scholar.google.com/scholar_lookup?

title=Integrated\%20territorial\%20and\%20urban\%20strategies\%3A\%20how\%20are\% 20ESIF\%2oadding\%20value\%20in\%202014\%E2\%80\%932020\%3F\%20European\%2 
oCommission\%2C\%20Directorate-

General\%2ofor\%2oRegional\%20and\%20Urban\%2oPolicy\%20and\%2oEuropean\%20

Policies\%20Research\%20Centre\%20\%28EPRC\%29\&author=A.\%20Zwet\&author=J.\% 20Bachtler\&author=M.\%20Ferry\&author=I.\%20McMaster\&author=S.\%20Miller\&pu

blication_year=2017)

\section{Copyright information}

(C) Springer Nature Switzerland AG 2019

\section{About this chapter}

Cite this chapter as:

Neto P., Serrano M.M., Santos A. (2019) Policy Cycle of the Urban Agenda for EU and Its Effects on Territorial Cohesion. In: Medeiros E. (eds) Territorial Cohesion. The Urban Book Series. Springer, Cham

- First Online 15 December 2018

- DOI https://doi.org/10.1007/978-3-030-03386-6_8

- Publisher Name Springer, Cham

- Print ISBN 978-3-030-03385-9

- Online ISBN 978-3-030-03386-6

- eBook Packages Earth and Environmental Science

- Buy this book on publisher's site

- Reprints and Permissions

\section{Personalised recommendations}

\section{SPRINGER NATURE}

(C) 2018 Springer Nature Switzerland AG. Part of Springer Nature.

Not logged in Universidade de Evora Rui Manuel Almeida Brandau (2000479569) - B-on Consortium Portugal (3991329481) 193.137.181.75 